DOI: $10.2478 / \mathrm{v} 10025-012-0001-4$

\title{
Current role of grasslands in development of agriculture and rural areas in Poland - an example of mountain voivodships małopolskie and podkarpackie
}

\author{
Halina JANKOWSKA-HUFLEJT ${ }^{1)}$, Barbara WRÓBEL ${ }^{1)}$, \\ Stanistaw TWARDY $Y^{2)}$
}

1) Institute of Technology and Life Sciences in Falenty, Department of Grassland, al. Hrabska 3, 05-090 Raszyn, Poland, phone +48 720-05-98, e-mail: H.Jankowska@itep.edu.pl

${ }^{2)}$ Institute of Technology and Life Sciences in Falenty, Małopolska Research Centre in Kraków, ul. Ułanów 21B, 31-450 Kraków, Poland, phone/fax +48 12 412-84-59, e-mail: itepkrak@itep.edu.pl

\begin{abstract}
In paper the current situation of agriculture activity in mountain areas in Poland on the example of two mountain voivodships: małopolskie and podkarpackie was presented. Particular the role of permanent grasslands in development of agriculture and rural areas was highlighted. The tools for support of agriculture development in mountain areas i.e. LFA payments, payments for cow and sheep raising were presented. The future prospects of the development of mountain areas in Poland were showed.
\end{abstract}

Key words: agriculture, fodder use, livestock, mountain regions development, permanent grasslands

\section{INTRODUCTION}

Substantial limitation of areas and use of PG in last years in Poland determinates economic (the loss of productive potential of grasslands) and biological (soil and floristic composition degradation) losses. The existence of meadow ecosystems is threatened, being dependent on agricultural activity by preventing the natural succession. Their environmentally protective function is threatened, consequently. Forest succession such as overgrowing of grasslands by trees and shrubs proceeds, soils, particularly organic soils, are being degraded. The coefficient of soil organic matter is negative and water capacity of soils is smaller. There is a deficit of manure used for fertilising both arable lands and meadows. Hence, the limitation of animal breeding decreases not only fodder production from PG but affects the production of arable lands. Fallow lands covered 462000 ha in 2008 and 498400 ha e.g. $3.1 \%$ of $\mathrm{AA}$ in 2009 . 
Permanent grasslands are important element of environment, particularly in mountain regions. Permanent grasslands in Polish Carpathians occupy $35-40 \%$ and sometimes $60-70 \%$ of total area of this region. Mountain areas are characterized by considerable specificity resulting not only from particular features of natural environment but also from a kind of services paid for economic and social needs of the whole country (TWARDY, 2009). Mountain areas should play many important functions set up in a hierarchical order: hydrologic function, leisure and health care, environmental protection and economic functions (water management, agriculture and forestry).

\section{GENERAL CHARACTERISTICS AND THE FODDER USE FROM PERMANENT GRASSLANDS IN POLAND}

Permanent grasslands (PG) are the main source of fodder for ruminants. Even if extensively used they provide natural, valuable fodder rich in carotene, vitamins, microelements and other substances catalysing the processing of bulk fodder into milk and other animal products. This fodder is also cheap. The proportions of costs dairy cows feeding with green fodder, silage, hay and cereal grains are 100\%, 130$150 \%, 180 \%$ and $350-500 \%$, respectively (REKLEWSKI and KRZYŻEWSKI, 1997).

PG occupy 3180 thousand ha (2009) in Poland i.e. $10 \%$ of the country area and c. $20 \%$ of agricultural areas (AA). Meadows cover $77 \%$ and pastures $-23 \%$ of permanent grasslands (Tab. 1). This is a very small area compared with other European countries where PG constitute c. $30 \%$ or more of AA. Moreover, the area of PG in Poland has diminished by nearly 1 million ha in the last decade.

Table 1. Recent changes in the area and land use structure of permanent grasslands

\begin{tabular}{|c|c|c|c|c|c|c|c|c|c|c|c|}
\hline \multirow{2}{*}{ Item } & \multicolumn{11}{|c|}{ Years } \\
\hline & 1996 & 2000 & 2001 & 2002 & 2003 & 2004 & 2005 & 2006 & 2007 & 2008 & 2009 \\
\hline Area, million ha & 4.13 & 3.85 & 3.8 & 3.56 & 3.27 & 3.37 & 3.39 & 3.22 & 3.27 & 3.18 & 3.18 \\
\hline $\begin{array}{l}\text { Percent of AA in- } \\
\text { cluding: }\end{array}$ & 23.1 & 21.9 & 21.7 & 21.1 & 20.2 & 20.6 & 21.3 & 20.2 & 19.8 & 19.7 & 19.7 \\
\hline meadows & 14.82 & 14.2 & 14 & 15 & 14.5 & 14.6 & 15.9 & 15 & 15.4 & 15.2 & 15.3 \\
\hline pastures & 8.28 & 7.7 & 7.7 & 6.1 & 5.7 & 6.0 & 5.4 & 5.2 & 4.4 & 4.5 & 4.4 \\
\hline
\end{tabular}

PG are often situated in extreme habitats where other plants could not be grown due to soil moisture or slope inclination. Therefore, they are unevenly distributed throughout Poland, mainly in river valleys and in foothill and mountain regions (Fig. 1). Contribution of good and very good soils under PG is small $(1.5 \%)$ whereas that of poorest soils exceeds $40 \%$. 


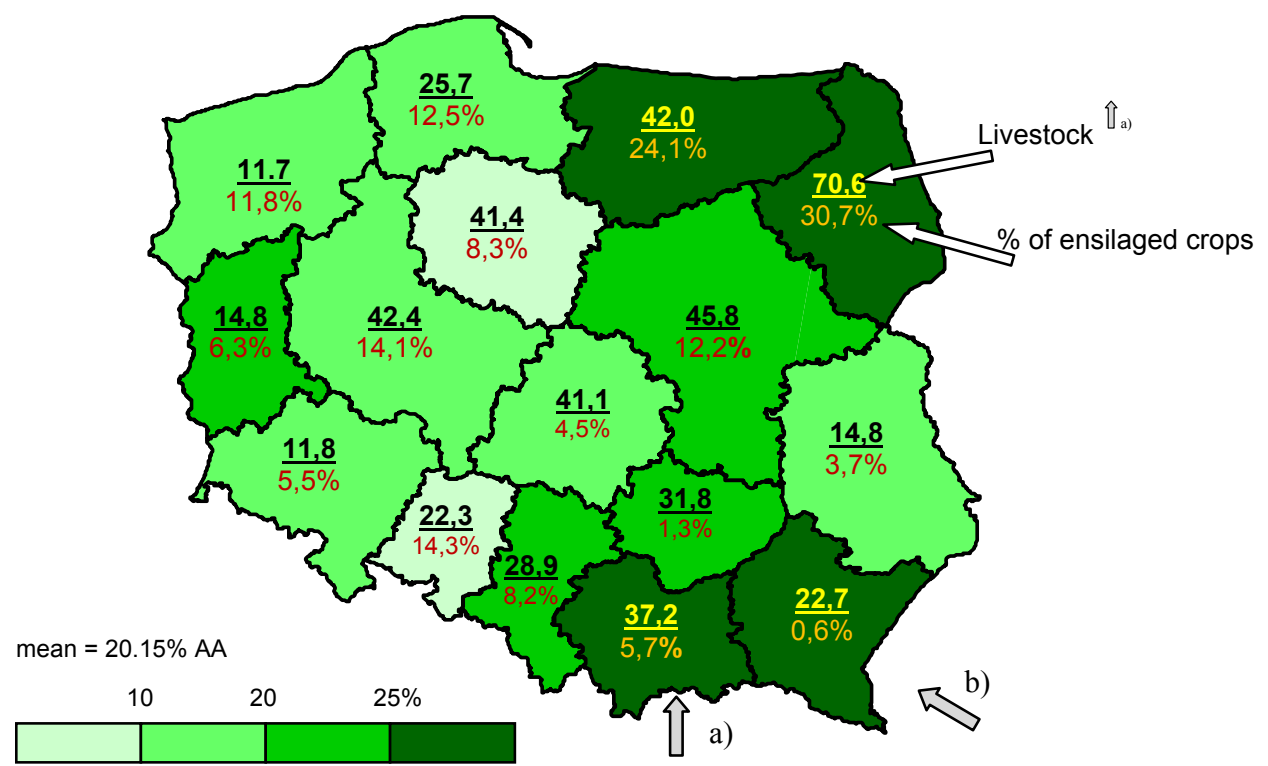

Fig. 1. Percent of PG in AA in Poland in particular voivodships (according to the legend), livestock (100 ha $\left.{ }^{-1} \mathrm{UR}\right), \%$ of ensilaged crops in voivodships; a) małopolskie, b) podkarpackie

Soils with good soil-agricultural complex (1z) represent only $2 \%$ of PG, medium soils $(2 z)-60 \%$ and poor and very poor soils (3z) $-38 \%$ of PG (Fig. 2$)$. The latter ones are usually situated in too dry or wet areas. Comparatively, nearly $50 \%$ of arable lands belong to complexes of unlimited crop selection.

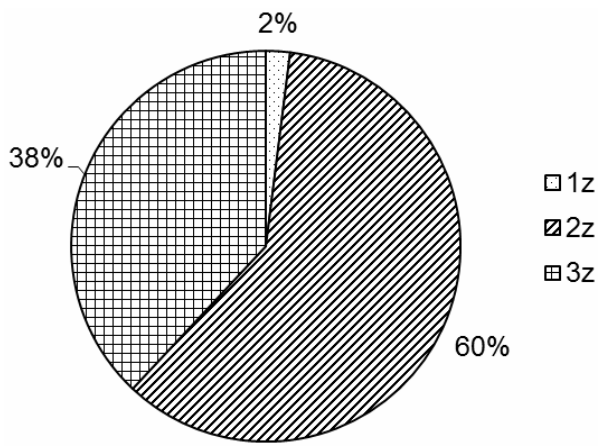

Fig. 2. Percentage share of soil-agriculture complexes of PG

Nevertheless, PG are the source of cheap and biologically valuable fodder for ruminants and other farm animals. The precondition of their existence is systematic biomass removal and grazing, those being the best ways of their use, not only for economic reasons. There is a close relationship between the quantity, quality and 
use of PG and the livestock, for that grassland sward is the main bulk fodder. This is evidenced by a decline in animal stock (cattle, sheep but also horses - Tab. 2, 3) that took place at the break of the $20^{\text {th }}$ and $21^{\text {st }}$ century resulting in insufficient utilisation of PG despite unquestioned value of grassland sward.

Table 2. The number of farm animals (thousand heads) in Poland (acc. to GUS)

\begin{tabular}{lrrrrrrrr}
\hline \multicolumn{1}{c}{ Stock } & \multicolumn{1}{c|}{1980} & \multicolumn{1}{c}{1990} & 2000 & 2004 & 2007 & \multicolumn{1}{c}{2009} \\
\hline Cattle & 12649 & 10049 & 6083 & 5353 & 5405.5 & 5700 \\
Sheep & 4207 & 4159 & 362 & 318 & 315.6 & 286 \\
Horses & 1780 & 941 & 550 & 320 & 500 & 298 \\
\hline
\end{tabular}

Table 3. Farm animal stock (head per 100 ha of AA) (acc. to GUS)

\begin{tabular}{c|c|c|c|c}
\hline \multirow{2}{*}{ Years } & \multicolumn{2}{|c|}{ Cattle } & \multirow{2}{*}{ Sheep } & \multirow{2}{*}{ Horses } \\
\cline { 2 - 3 } & total & dairy cows & & \\
\hline 1980 & 66.8 & 31.4 & 22.2 & 9.4 \\
2004 & 32.8 & 17.1 & 1.9 & 2.0 \\
2007 & 33.6 & 16.9 & 1.95 & 3.1 \\
2009 & 35.4 & 16.7 & 1.8 & 1.8 \\
\hline
\end{tabular}

A regress in animal production has been noted since 1980. Livestock decreased by more than 56\% until 2009 and sheep breeding became marginal (Tab. 2). Cattle stock decreased two times between 1980 and 2004, horse stock - almost five times and sheep stock - nearly 12 times being only 1.9 head per 100 ha AA (Tab. 3). Payments for the agricultural production since Polish has accessed the European Union have initiated some positive changes. Cattle stock increased from 32.8 in 2004 to 35.4 head $(100 \mathrm{ha})^{-1}$ AA in 2009 . The number of dairy cows has decreased while that of beef cattle has increased. Farms that did not achieve the required veterinary standards were out-competed from milk production. An additional limitation came from imposed low milk quota. However the decline in the number of dairy cows did not translate into milk production. Mean milk efficiency of 45961 per cow in 2009 increased by about 14301 as compared with that in 1990 (Produkcja ..., 2010). Improved milk efficiency results from the restructuring and concentration of milk production and from the progress in fodder production and feeding quality. In podlaskie voivodship (the leader in cattle breeding) cattle stock is almost twice than the country mean and the percent of ensilaged grassland fodder is highest (Fig. 1).

Present productive use of PG is still insufficient due to extensive farming. Yielding is low (Tab. 4) and hay instead of silage is still the main product. The area of pastures decreased by half during from 1996 to 2009 (Tab. 1). Moreover, only $50-74 \%$ (mean $67 \%$ ) of meadows is used as fodder sources and $9-16 \%$ is not 
mown at all despite of the subsidies for mowing (Tab. 5). Yields from meadows have recently been collected in $65 \%$ as hay. Ten and nine percent were intended for silage and current feeding, while $17 \%$ of meadows were grazed (Produkcja..., 2005; 2006; 2007).

Table 4. Hay yields $\left(\mathrm{t} \cdot \mathrm{ha}^{-1}\right)$ from PG acc. to GUS

\begin{tabular}{l|c|c|c|c|c|c}
\hline \multirow{2}{*}{\multicolumn{1}{c}{ Grassland }} & \multicolumn{5}{c|}{ Years } & \multirow{2}{*}{ Mean } \\
\cline { 2 - 6 } & 2005 & 2006 & 2007 & 2008 & 2009 & \\
\hline Meadow & 4.28 & 3.85 & 5.18 & 4.84 & 4.92 & 4.61 \\
I cut & 2.39 & 2.40 & 2.64 & 2.62 & 2.38 & 2.49 \\
II cut & 1.33 & 0.74 & 1.72 & 1.46 & 1.72 & 1.39 \\
III cut & 0.56 & 0.71 & 0.82 & 0.76 & 0.82 & 0.73 \\
Pasture $^{1)}$ & 3.12 & 2.76 & 3.56 & 3.48 & 4.08 & 3.40 \\
\hline
\end{tabular}

${ }^{1)}$ Fresh fodder recalculated for hay with the factor 0.2 .

Table 5. Utilisation of meadows (\%)

\begin{tabular}{l|c|c|c|c|c|c}
\hline \multirow{2}{*}{ Specification } & \multicolumn{5}{c|}{ Years } & \multirow{2}{*}{ Mean } \\
\cline { 2 - 6 } & 2005 & 2006 & 2007 & 2008 & 2009 & \\
\hline Fodder & 60.8 & 50.3 & 76.3 & 74.4 & 74.6 & 67.3 \\
Other purposes $^{1)}$ & 23.2 & 34.3 & 12.8 & 17.0 & 14.1 & 20.3 \\
Not used & 16.0 & 15.4 & 10.9 & 8.6 & 11.3 & 12.4 \\
\hline
\end{tabular}

${ }^{1)}$ Mowing for payments, compost, litter.

\section{THE SPECIFICS OF FOOTHILL AND MOUNTAIN REGIONS IN POLAND}

Ninety percent of PG in Poland is associated with river valleys or land depressions of a high ground water level; the remaining $10 \%$ represents grasslands in mountain areas with high atmospheric precipitation level.

Mountain regions above $300 \mathrm{~m}$ a.s.l. occupy 27 thousand $\mathrm{km}^{2}(8.7 \%$ of the country area). They are built of three mountain ranges: the Carpathians (19 600 $\mathrm{km}^{2}$ ), the Sudetes $\left(4800 \mathrm{~km}^{2}\right)$ and the Świętokrzyskie Mountains $\left(3200 \mathrm{~km}^{2}\right)$. The elevations $300-500 \mathrm{~m}$ a.s.1. occupy $5.7 \%$ of the country area, those in the range 500-1000 m a.s.1. $-2.9 \%$ and high mountains above $1000 \mathrm{~m}$ a.s.1. - only $0.1 \%$ of Poland (KOSTUCH, 1976; TWARDY, 1993).

Rich natural forms of these areas create attractive conditions for the development of various agricultural activities and technical infrastructure compared with other regions of the country. The largest areas are used for agriculture and forestry (50 and 39\% of the area, respectively) (KOPEĆ, 1995). The largest areas occupied by farms can be found in małopolskie (53.1\%), dolnośląskie (19.5\%) and podkarpackie (19.0\%) voivodships. 
The specifics of particular mountain regions results not only from particular features of natural environment but also from a kind of services paid for economic and social needs of the whole country (TWARDY, 2009). Mountain areas should play many important functions set up in a hierarchical order: hydrologic function, leisure and health care, environmental protection and economic functions (water management, agriculture and forestry).

Due to temperature, precipitation, duration of the vegetation period, elevation and slope inclination mountain areas were used as arable lands but mainly as grasslands up to the elevation of $700 \mathrm{~m}$ a.s.l., sometimes higher. The areas are characterised by a similar index of soil usefulness for agriculture (Niskonakładowa..., 2001). Farming conditions of podkarpackie and małopolskie voivodships are typical for mountain and foothill regions. Therefore, the description of the role and utilisation of PG in mountain areas is based on these two examples.

\section{CHARACTERISTICS OF AGRICULTURE IN PODKARPACKIE AND MAŁOPOLSKIE VOIVODSHIPS}

Agricultural areas occupy $42 \%$ and $45 \%$ of the total area of podkarpackie and małopolskie vivodships, respectively. Arable lands prevail in $66 \%$ and $63 \%$, respectively (Tab. 6). Percent of fallow and barren lands decreased from $6.7 \%$ in 2000 to $4.5 \%$ in 2009 in małopolskie voivodship and from 13.25 to $9.0 \%$ in the same time period in podkarpackie voivodship.

Table 6. Land use of mountain areas on the background of the country (Użytkowanie..., 2009)

\begin{tabular}{l|c|c|c}
\hline \multicolumn{1}{c|}{ Specification } & $\begin{array}{c}\text { Małopolskie } \\
\text { voivodship }\end{array}$ & $\begin{array}{c}\text { Podkarpackie } \\
\text { voivodship }\end{array}$ & Poland \\
\hline Surface area of AA, thousand ha & 690.7 & 746.8 & 16119.6 \\
- arable lands, \% & 62.7 & 65.9 & 75.1 \\
- orchards, \% & 2.3 & 1.4 & 2.1 \\
PG in total & 31.57 & 28.17 & 19.73 \\
- meadows, \% & 25.15 & 22.35 & 15.28 \\
- pastures, \% & 6.42 & 5.82 & 4.45 \\
- other, \% & 3.51 & 4.47 & 3.07 \\
Forests and forest grounds, thousand ha & 437.4 & 671.0 & 9272.6 \\
- \% of total area & 28.8 & 38.0 & 29.2 \\
Fallow and barren lands, \% AA & 4.5 & 9.0 & 3.1 \\
\hline
\end{tabular}

Moreover the consumption of mineral fertilisers was always low in mountain regions, lower than the country mean and it still decreases (Fig. 3). This is partly a result of the development of low-input or organic farming where the chemical fertilisers are not used. 


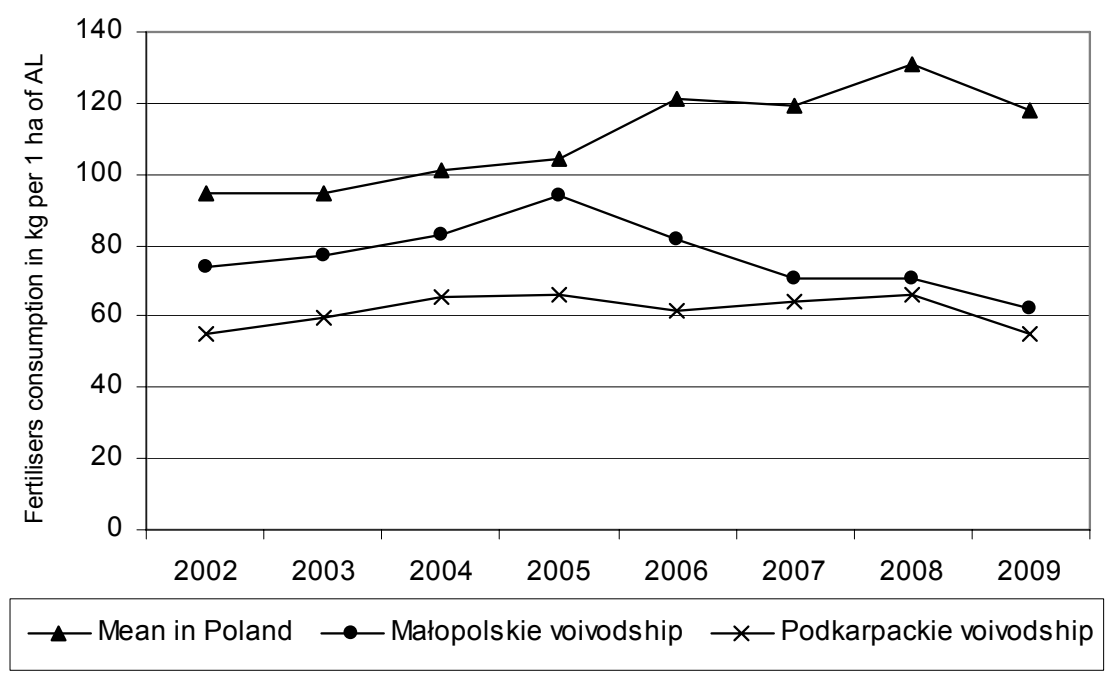

Fig. 3. Consumption of NPK fertilisers

Agriculture in małopolskie voivodship is quite differentiated. In northern part, farm areas are larger, this being partly an effect of its lower altitude. Smaller farms with developed mountain and fruit farming dominate in south-east part of the region (Program..., 2011).

Podkarpackie voivodship has little more favourable natural conditions despite quite variable land relief. Soils of the III, IV and V quality class prevail in both voivodships (84.7\% AA in małopolskie and $87.3 \%$ AA in podkarpackie voivodship). Very poor soils (VI class intended for afforestation) cover $8.6 \%$ AA in małopolskie voivodship and $7.4 \%$ AA in podkarpackie voivodship. The share of the best soils (I and II class) is negligible. Acidification is the factor that decreases significantly soil quality. Liming is required in $70 \%$ of AA from both voivodships.

Most farms in both voivodships had an area of less than 1.0 ha in 2009 (Fig. 4). They represent over $40 \%$ out of the total area of 296.6 thousand ha in podkarpackie voivodship and 310.6 thousand ha in małopolskie voivodship. Mean AA surface in a farm from podkarpackie voivodship was 2.8 ha and 2.23 ha in małopolskie voivodship. The country mean was 6.27 ha.

The farms in both voivodships are highly dispersed despite their small area. As many as $24.7 \%$ of farms use six or even more separate plots. This does not favour new technologies and stimulates the development and progress in agriculture of the region (Niskonakładowa..., 2001). Combined with generally lower technologies it makes the labour inputs per plant production unit higher by $30-50 \%$ and those per animal production unit by $20-30 \%$ higher than the respective inputs in lowland agriculture (JANKOWSKA-HUFLEJT and PROKOPOWICZ, 2011). 


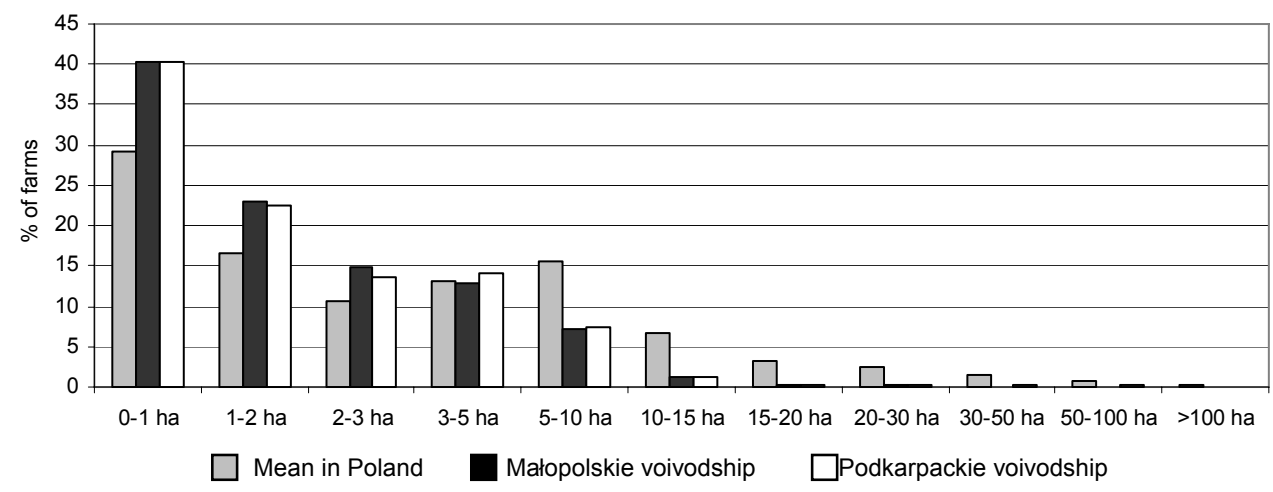

Fig. 4. Percent of tarms in the groups of surface area (Statistical Y earbook of Agriculture, 2010)

Dispersion of production determinates the profitability decrease of dairy cow breeding. Purchase prices (per 1001 without VAT) were also lowest in mountain voivodships (91.69 and $92.04 \mathrm{zl}$ in podkarpackie and małopolskie voivodships, respectively as compared with $106.58 \mathrm{zł}$ country mean). Limiting dispersion of milk production should improve the technological level of production. However, the most important for grassland management is the price relationships between animal products and appropriate merchandising. Milk production is still too low in relationship with the potential consumption of dairy products which makes a chance for the development of economically effective dairy farms in Poland.

\section{THE USE OF PERMANENT GRASSLANDS ON THE BACKGROUND OF AGRICULTURAL AREAS}

Permanent grasslands are present in most of the farms from the regions described previously. Their share in AA is significantly higher than the country mean (Tab. 6). They usually occupy sites inappropriate for field crops due mainly to soil features, elevation and situation on mountain slopes. Their share in feeding areas for ruminants in 2009 amounted $78.8 \%$ in małopolskie voivodship and $85.2 \%$ in podkarpackie voivodship (Produkcja..., 2010). Mean hay yield from meadows harvested during 2000-2009 was $4.5 \mathrm{t} \cdot \mathrm{ha}^{-1}$ in małopolskie voivodship, $4.08 \mathrm{t} \cdot \mathrm{ha}^{-1}$ in podkarpackie voivodship and the country mean was $4.3 \mathrm{t} \cdot \mathrm{ha}^{-1}$ (Tab. 7).

Vegetation of mountain PG is more diverse than in lowlands. There are more plant species communities and floristic types. This effect is due to variable habitat factors (elevation, relief, exposure, slope inclination, trophic status and moisture) and to the way of sward utilization (Niskonakładowa..., 2001). According to JAGŁA et al. (1971) the most important communities decisive for global fodder production of grassland include: typically pasture community Lolio-Cynosuretum, grassland community Gladiolo-Agrostidetum and natural or sown grassland are 
Table 7. Grassland yielding in the years 2000-2009 acc. to GUS

\begin{tabular}{|c|c|c|c|c|c|c|c|c|c|c|}
\hline \multirow{2}{*}{$\begin{array}{c}\text { Poland } \\
\text { voivodship }\end{array}$} & \multirow{2}{*}{2000} & \multirow{2}{*}{2002} & \multirow{2}{*}{2004} & \multirow{2}{*}{2006} & \multirow{2}{*}{2007} & \multirow{2}{*}{2008} & \multicolumn{4}{|c|}{2009} \\
\hline & & & & & & & total & I cut & II cut & III cut \\
\hline \multicolumn{11}{|c|}{ Hay yields from permanent meadows, $t \cdot h^{-1}$} \\
\hline Polska & 3.82 & 4.17 & 4.4 & 3.71 & 5.17 & 4.83 & 4.92 & 2.38 & 1.72 & 0.83 \\
\hline Małopolskie & 4.65 & 4.81 & 4.6 & 4.04 & 4.46 & 4.54 & 4.27 & 2.26 & 1.44 & 0.56 \\
\hline Podkarpackie & 4.20 & 4.4 & 4.26 & 3.42 & 4.07 & 4.38 & 4.19 & 2.24 & 1.46 & 0.49 \\
\hline \multicolumn{11}{|c|}{ Fresh fodder yields from pastures, $t \cdot h a^{-1}$} \\
\hline Polska & 15.2 & 15.4 & 16.8 & 13.8 & 17.8 & 17.4 & 20.4 & & & \\
\hline Małopolskie & 20.8 & 18.7 & 16.8 & 14.1 & 14.2 & 14.7 & 14.6 & & & \\
\hline Podkarpackie & 15.4 & 14.7 & 14.2 & 9.4 & 13.7 & 12.7 & 11.9 & & & \\
\hline
\end{tabular}

forming the community Arrhenatheretum elatioris. The most productive is Arrhenatheretum elatioris from among mown grasslands and Lolio-Cynosuretum among pastures. The least productive community is that with Nardus stricta gradually declining due to the utilization.

Satisfactory yield increases and fodder quality improvement can be achieved from these communities after mineral fertilisation with $100-120 \mathrm{~kg} \mathrm{~N}, 30-40 \mathrm{~kg} P$ and $60-80 \mathrm{~kg} \mathrm{~K}$ per ha. However, transformation of Nardus stricta degraded communities needs, more sophisticated management like full cultivation, penning (if possible) with sub-sowing of valuable grass and legume species (Niskonakładowa..., 2001; TWARDY, 1998).

The use of meadows in both voivodships was different. The share of not exploited or mown but not harvested meadows was smaller in małopolskie voivodship (Tab. 8). That in podkarpackie voivodship was larger than the country mean

Table 8. The use of meadows for different purposes in subsequent cuts in 2009

\begin{tabular}{l|c|c|c|c}
\hline \multirow{2}{*}{$\begin{array}{c}\text { Poland } \\
\text { voivodship }\end{array}$} & \multicolumn{4}{c}{ Meadows } \\
\cline { 2 - 5 } & grass harvested for fodder & grazed & mown but not harvested & not exploited \\
\hline \multirow{3}{*}{ Poland } & $\mathbf{7 5 . 3}$ & I cut & \\
Małopolskie & 78.6 & $\mathbf{8 . 4}$ & $\mathbf{5 . 0}$ & $\mathbf{1 1 . 3}$ \\
Podkarpackie & 70.0 & 7.0 & 5.9 & 8.5 \\
& & 10.5 & 6.5 & 13.0 \\
Poland & $\mathbf{6 7 . 6}$ & II cut & & $\mathbf{1 4 . 1}$ \\
Małopolskie & 69.1 & $\mathbf{1 5 . 5}$ & $\mathbf{2 . 8}$ & 12.2 \\
Podkarpackie & 56.3 & 16.5 & 2.2 & 19.2 \\
& & 19.6 & 4.9 & $\mathbf{2 6 . 8}$ \\
Poland & $\mathbf{4 1 . 7}$ & III cut & & 24.0 \\
Małopolskie & 35.3 & $\mathbf{2 9 . 9}$ & $\mathbf{1 . 6}$ & 44.2 \\
Podkarpackie & 26.7 & 39.3 & 1.4 & \\
\hline
\end{tabular}


and in the third cut it amounted as much as $44 \%$. The latter region is dominated by once and less frequently by twice cut meadows. Such frequency is typical for extensive farming. It allows to infer that grasslands in this region will rather play environmental than productive functions in the future (BARSZCZEWSKI et al., 2009). Yields from permanent meadows are used in a slightly different way in the two voivodships, though they are mainly harvested for hay (in $61 \%$ in małopolskie and $70 \%$ in podkarpackie voivodships in 2009). Silage is more popular in małopolskie voivodship (12\% ensilaged fresh fodder) than in podkarpackie voivodship (less than $3 \%$ ). The rest of yields is intended for fresh fodder in current feeding or is grazed (Tab. 9).

Table 9. The structure of yields from meadows in 2009

\begin{tabular}{l|c|c|c|c}
\hline \multirow{2}{*}{$\begin{array}{c}\text { Poland } \\
\text { voivodship }\end{array}$} & \multicolumn{4}{|c}{ Utilisation of yields from meadows, \% } \\
\cline { 2 - 5 } & hay & silage & fresh fodder & grazed \\
\hline Poland & 51.4 & 23.3 & 9.3 & 16.0 \\
Małopolskie & 61.5 & 11.7 & 11.2 & 15.6 \\
Podkarpackie & 70.5 & 2.7 & 7.2 & 19.6 \\
\hline
\end{tabular}

\section{LIVESTOCK IN MOUNTAIN AREAS}

Present status and the use of PG are closely related to livestock - the consumers of produced fodder (Tab. 10). Animals, mainly cattle and sheep, are the factor affecting the ways, intensity and utilisation of PG (JANKOWSKA-HUFLEJT et al., 2009). Unfortunately, farm animal stock in both voivodships is still smaller than before (Tab. 2, 3) and the production of manure and liquid manure is still insufficient.

Table 10. The number of cattle, sheep, horses and goats in LU in 2009

\begin{tabular}{l|r|r|r|r}
\hline $\begin{array}{c}\text { Poland } \\
\text { voivodship }\end{array}$ & Cattle & Sheep & Horses & Goats \\
\hline Poland & 4235085 & 28638 & 357530 & 11884 \\
Małopolskie & 154976 & 9448 & 34934 & 1446 \\
Podkarpackie & 119205 & 1367 & 22271 & 1392 \\
\hline
\end{tabular}

In 2009 the livestock was smaller by 11 heads per 100 ha in podkarpackie voivodship and by 16 heads in małopolskie voivodship as compared with the livestock in 2000 . However, the stock of sheep increased by $100 \%$ in małopolskie voivodship and in podkarpackie voivodship it is now similar to the country mean (Tab. 11). 
Table 11. Livestock, heads per 100 ha AA

\begin{tabular}{l|c|c|c|c|c|c|c|rr}
\hline \multirow{2}{*}{$\begin{array}{c}\text { Poland } \\
\text { voivodship }\end{array}$} & \multicolumn{2}{|c|}{ Farm animals LU per 100 ha AA } & \multicolumn{3}{c|}{ Cattle } & \multicolumn{3}{c}{ Sheep } \\
\cline { 2 - 11 } & 2000 & 2005 & 2009 & 2000 & 2005 & 2009 & 2000 & 2005 & 2009 \\
\hline Poland & 40.5 & 46.8 & 43.6 & 33.0 & 34.5 & 35.4 & 2.0 & 2.0 & 1.8 \\
Małopolskie & 44.1 & 46.5 & 36.0 & 44.3 & 38.4 & 28.4 & 6.9 & 12.0 & 13.7 \\
Podkarpackie & 30.8 & 29.9 & 23.7 & 30.6 & 23.6 & 19.6 & 1.5 & 2.5 & 1.8 \\
\hline
\end{tabular}

\section{SUPPORTING AGRICULTURE DEVELOPMENT IN MOUNTAIN AREAS}

Less favoured areas. Mountain areas are classified as less favoured areas (LFA) since they have the worst agro-climatic conditions and the index of agricultural evaluation of productive space (AEPS) is almost half that in areas that do not need support (Tab. 12). Limited possibilities of field production (extreme climatic conditions, slope inclination) result in low efficiency, deteriorating the life conditions and leading to the depopulation of mountain areas.

Table 12. Comparison of productive conditions in LFA and other areas (acc. to PROW 2004-2006) mean values of indices (TWARDY, 2008)

\begin{tabular}{|c|c|c|c|c|c|}
\hline Parameters & $\begin{array}{l}\text { Mountain } \\
\text { LFA }\end{array}$ & $\begin{array}{l}\text { LFA with } \\
\text { handicap }\end{array}$ & $\begin{array}{l}\text { Lowland } \\
\text { LFA II }\end{array}$ & $\begin{array}{c}\text { Lowland } \\
\text { LFA I }\end{array}$ & $\begin{array}{c}\text { Grounds } \\
\text { outside LFA }\end{array}$ \\
\hline AEPS index & 42.7 & 56.4 & 48.6 & 59.9 & 75.7 \\
\hline Percent of PG & 60.3 & 40.9 & 29.4 & 21.4 & 12.9 \\
\hline Percent of fallow lands & 50.0 & 39.9 & 26.1 & 15.5 & 7.0 \\
\hline $\begin{array}{l}\text { Productivity, } \% \text { of the } \\
\text { country mean }\end{array}$ & -74 & -63 & -39 & -19 & +1 \\
\hline Mean productivity PLN $\cdot h^{-1}$ & 607 & 848 & 1409 & 1850 & 2319 \\
\hline
\end{tabular}

Therefore, mountain areas are supported by „LFA payments” according to the government Programme for the Development of Rural Areas 2007-2013. According to Poland's law, communes are qualified as mountain LFA if more than $50 \%$ of their AA is situated higher than $500 \mathrm{~m}$ a.s.l. (Appendix 2 to the Government Decree of $14^{\text {th }}$ April 2004). There are 93 communes that fulfil this criterion. They are situated in 22 counties and 4 voivodships: dolnośląskie, śląskie, małopolskie and podkarpackie.

According to the Agency for Restructuring and Modernization of Agriculture the payments to LFA in 2009 were amounted at 52.11 million PLN in małopolskie voivodship and 45.439 million PLN in podkarpackie voivodship which represented $7.2 \%$ of all LFA subsidies in the country.

The next support for agriculture in mountain areas and chance for restoration of farm animal breeding is a new payment for cow and sheep breeding (and also 
for planting legumes and pulses) introduced in 2010 within the system of direct support of specific types of production. These payments amount 40.8 million euro per year including 28.5 million euro subsidy for cow breeding (142.5 euro per capita) and 1.5 million euro for sheep breeding (about 30 euro per capita). Farmers from 5 voivodships of southern Poland (podkarpackie, małopolskie, śląskie, opolskie and dolnoślaskie) are entitled to this subsidy. Applying farmer must have a herd of up to 10 cows or at least 10 sheep at the age of at least 18 months.

\section{PROSPECTS OF THE DEVELOPMENT OF MOUNTAIN AREAS IN POLAND}

Most mountain areas are peripheral, hardly accessible grounds with intensified processes of economic and demographic marginalization (DAX and WIESINGER, 2007). According to SROKA (2008) these processes progress less intensively in Polish mountain areas and will be further mitigated in the next decade through implementation of broadly understood sustainable development. However, the prerequisite is the rational use of local and regional natural resources.

Due to socially unfavourable depopulation of upper mountain ranges, any non-agricultural activity should be assessed positively. Development is possible in agri-tourism with accompanying services like holding events, catering etc. Agriculture with the use of PG should remain as the basic and necessary activity due to the services it renders to cultural landscape, natural biodiversity, protection for erosion, water cycle and water quality.

A positive feature of transformation in grassland management (particularly in mountain areas) is the acknowledgement of their importance for natural environment. In Poland, as in the old EU member countries, the area involved in agrienvironmental programmes and other payments enforcing protection and maintenance of PG continuously increases. Multifunctional character of PG combines the intensity of their use with protective effect on natural environment.

Organic production in mountain regions may be a chance for the development of small and medium size farms. Natural conditions, agricultural structure and social aspects weigh in favour of this option which is confirmed by the number of organic farms increasing from year to year. Between the years 2004 (Polands' access to the EU and implementation of payments) and 2009 the number of organic farms doubled in małopolskie voivodship and increased by 2.5 times in podkarpackie voivodship (Tab. 13). In 2009 the total area of organic farms was 11766 ha in małopolskie and 16766 ha in podkarpackie voivodship.

Small farms which sought a chance for increasing their incomes and remaining in the market were most numerous among organic farms. Farms of an area of less than 5 ha constituted $30 \%$ of organic farms in podkarpackie voivodship and $59 \%$ in małopolskie voivodship. 
Table 13. The number of organic farms

\begin{tabular}{l|r|r|r|r|r}
\hline \multicolumn{1}{c}{$\begin{array}{c}\text { Poland } \\
\text { voivodships }\end{array}$} & 2005 & 2006 & 2007 & 2008 & 2009 \\
\hline Poland & 1463 & 9187 & 11870 & 14896 & 17091 \\
Małopolskie & 1187 & 1363 & 1627 & 2100 & 2197 \\
Podkarpackie & 855 & 1164 & 1577 & 1892 & 2014 \\
\hline
\end{tabular}

In the years 2005-2008 were performed studies on 9 organic farms (5 in małopolskie and 4 in podkarpackie voivodships) from Polish Carpathians (500 $1000 \mathrm{~m}$ a.s.l.) in the framework of a project of the Ministry of Agriculture and Rural Development (Badania..., 2009). Farms raised herbivorous animals. The average participation of PG in AA in examined farms was 76\% (range from 35-100\%). Surface area of organic farms ranged from 3 to 53 ha (32 ha in podkarpackie and 17.6 ha in małopolskie voivodship as the mean) which markedly exceeded the mean farm area in those voivodships. The dominant species breeded was cattle, followed by sheep and goat. Obtained results showed that at 50\% share of PG in AA such production is justified and provides plant diversity, grassland stability and good economic indices. Calculated balance of bulk fodder was equilibrated in most of the farms but sometimes showed excess or deficit. Large excess resulted from too small livestock or too high yield estimates. Smaller farms used also c. $30 \%$ of arable fields for planting, apart from potatoes, fodder plants (mainly mixtures of grasses and legumes) (Badania..., 2009).

Supporting the development of sustainable agriculture (including organic farming) is prospective for economic reasons, justified by the existing food base and necessary to maintain biological balance and to protect environmental values.

\section{SUMMARY}

In the very nature of things, agriculture in mountain areas is less efficient, more costly and hence less competitive and financially unattractive. Even specific equipment will not markedly change its unfavourable relations with the potential of lowland agriculture. Therefore, following the example of Alpine countries, agriculture in mountain areas must be dealt with as one of basis for permanent land use to protect natural and cultural values and the existing infrastructure. Organic farms able to fulfil the task of environmental protection and landscape management through the productive care of PG have a new chance in this aspect.

With respect to natural values of mountain areas, market agricultural production should be directed to dairy and beef ruminant breeding based on the own fertiliser and fodder base from grasslands and from fodder crops. This production might be the main source of incomes for farmers. Sheep breeding is one of the 
niche directions in animal production which still has a chance for further development.

Functioning of mountain agriculture based on a large share of PG is a guarantee for maintaining many non-market farms whose role is limited to food production for own needs, to supporting social functions and preserving local traditions and culture.

\section{REFERENCES}

1. Badania nad wpływem pasz pochodzenia łąkowo-pastwiskowego na produkcję zwierzęcą w gospodarstwach ekologicznych, 2005; 2006, 2007, 2008, 2009. Raport naukowy z realizacji projektu badawczego MRiRW, kierowanego przez. H. Jankowską-Huflejt. (Studies on the effect of grassland fodder on livestock production in organic farms. 2005, 2006, 2007, 2008, 2009. Reports from a grant awarded by the Ministry of Agriculture and Rural Development to H. Jankowska-Huflejt).

2. Barszczewski J., Wasilewski Z., JankowsKa-Huflejt H., WróBel B., 2009. Stan i perspektywy wykorzystania trwałych użytków zielonych w Polsce. (Status and perspectives of permanent grassland use in Poland). Studia i Raporty Wydaw. IUNG-PIB. Nr 17-2009: 59-71.

3. Charakterystyka gospodarstw rolnych w $2007 \mathrm{r}$. (Characteristics of farms in the year 2007). 2008. Warszawa, GUS.

4. DaX T., Wiesinger G., 2007. Der Marginalisierung entgegenwirken: Nachhaltige Entwicklung der Berglandwirtschaft, Ländlicher Raum, Online-Fachzeitschrift des Bundesministeriums für Land- und Fortswirtschaft, Jgg. 2007, http://www.laendlicher-raum.at/, access on 1 April 2008.

5. JAGŁa S., Kopeć S., Kostuch R., 1971. Charakterystyka oraz możliwości produkcyjne ważniejszych zbiorowisk roślinnych górskich użytków zielonych. (Characteristic and production possibilities of more important plant communities of mountain grasslands). Wyd. RRZD WysokaWrocław

6. JANKowsKa-Huflejt H., BARSZCZEwski J., MoraCZEwSKi R., 2009. Uwarunkowania i stan gospodarowania na użytkach zielonych w kraju i w woj. podlaskim. (Determinants and grassland management in the country and in podlaskie voivodship). Wiadomości Melioracyjne i Łąkarskie, 2: 73-77.

7. JANKOwSKA-Huflejt H., DOMAŃSKi P.J., 2008. Aktualne i możliwe kierunki wykorzystania trwałych użytków zielonych w Polsce. (Present and possible directions of grassland use in Poland). Woda Środowisko Obszary Wiejskie t. 8 z. 2 b (24): 31-49.

8. JANKOwSKa-Huflejt H., ProkopowiCz J., 2011. Wpływ wybranych czynników produkcyjnoekonomicznych na rozwój górskich i nizinnych łąkarskich gospodarstw ekologicznych w latach 2004-2009. Journal of Research and Applications in Agricultural Engineering, 56(3): 158-163.

9. Kostuch R., 1976. Przyrodnicze podstawy gospodarki łąkowo-pastwiskowej w górach. (Natural foundations of grassland management in the mountains). Warszawa, PWRiL: 1-152.

10. KoPEĆ S., 1995. Znaczenie górskich użytków zielonych w ochronie wód. Annales UMCS, Sect. E, 50: 311-316.

11. Niskonakładowa produkcja rolnicza $\mathrm{z}$ wykorzystaniem pasz z użytków zielonych $\mathrm{w}$ Karpatach Polskich. 2001. (Low-input agricultural production with the use of fodder from grasslands in Polish Carpathians). Eds H. Jankowska-Huflejt, J. Zastawny. Falenty, Wydaw. IMUZ: 1-202.

12. Produkcja upraw rolnych i ogrodniczych w 2006 r. (do 2009). (Agricultural and orchard crops in the years 2006-2009) 2007, 2008, 2009, 2010. Warszawa, GUS.

13. Program rolny dla województwa małopolskiego. (Agricultural programme for małopolskie voivodship). http://nowoczesnawies.pl/index.php?option=com_content\& view=article $\& \mathrm{id}=84$ : 
program-rolny-dla-wojewodztwa-maopolskiego\&catid=37:programy-wojewodzkie\&Itemid=57 access on 5 May 2011.

14. Program rolny dla województwa podkarpackiego. (Agricultural programme for podkarpackie voivodship). http://nowoczesnawies.pl/index.php?option=com_content\& view=article\&id=87: program-rolny-dla-wojewodztwa-podkarpackiego\&catid=37:programy-wojewodzkie\&Itemid=57 - access on 5 May 2011.

15. Program Rozwoju Obszarów Wiejskich na lata 2007-2013 (Programme for the Development of Rural Areas in the years 2007-2013). (PROW 2007-2013). Warszawa, MRiRW.

16. Raport o stanie rolnictwa ekologicznego w Polsce w latach 2005-2006. 2007. (Report on the status of organic farming in Poland in the years 2005-2006). Warszawa, Główny Inspektorat Jakości Handlowej Artykułów Rolno-Spożywczych. http://www.ijhar-s.gov.pl/pliki/download/ Raport_eko.pdf - access on 30 April 2011.

17. REKLEWSKI Z., KRZYŻEWSKI J. (eds), 1997. Chów i hodowla zwierząt gospodarskich. (Raising and breeding of farm animals). Warszawa, Wydaw. Rozwój SGGW: 1-284.

18. Rocznik statystyczny rolnictwa 2009, 2010. (Statistical Yearbook of Agriculture). Warszawa, GUS.

19. Rolnictwo ekologiczne w Polsce. Raport 2007-2008, 2009. (Organic farming in Poland. Report 2007-2008). Warszawa, Główny Inspektorat Jakości Handlowej Artykułów Rolno-Spożywczych. http://www.ijhar-s.gov.pl/pliki/download/RAPORT2007-2008.pdf - access on 30 April 2011

20. Rozporządzenie Ministra Rolnictwa i Rozwoju Wsi z dnia 11 kwietnia 2007 r. w sprawie szczegółowych warunków i trybu przyznawania pomocy finansowej w ramach działania „Wspieranie gospodarowania na obszarach górskich i innych obszarach o niekorzystnych warunkach gospodarowania (ONW)", objętej Programem Rozwoju Obszarów Wiejskich na lata 2007-2013. (Decree of the Minister of Agriculture and Rural Development of 11 April 2007 on detailed conditions and mode of granting financial support within the action:"Supporting management in mountain areas and other LFA involved in the Programme for Development of Rural Areas in the years 2007-2013) Dz.U. 2007.68.448.

21. Rozporządzenie Rady Ministrów z dnia 14 kwietnia 2004 r. w sprawie szczegółowych warunków i trybu udzielania pomocy finansowej na wspieranie działalności rolniczej na obszarach o niekorzystnych warunkach gospodarowania objętej planem rozwoju obszarów wiejskich. (Decree of the Government of 14 April 2004 on detailed conditions and mode of granting financial support to agricultural activity in LFA involved in the plan of development of rural areas). Dz.U. 2004.73. 657.

22. SRoKa W., 2008. Perspektywy rozwoju obszarów górskich w Polsce i w Niemczech. (Perspectives of the development of mountain areas in Poland and in Germany). Problemy Zagospodarowania Ziem Górskich, 55: 41-53.

23. TWARDY S., 1993. Warunki przyrodnicze a użytkowanie ziemi w Karpatach. (Natural conditions and land use in the Carpathians). Postępy Nauk Rolniczych, 3: 51-60.

24. TWARDY S., 2008. Karpackie użytki rolne jako obszary o niekorzystnych warunkach gospodarowania (ONW). (Carpathian agricultural lands as less favoured areas). Woda Środowisko Obszary Wiejskie, 8, 2b (24): 191-202.

25. TWARDY S., 2009. Tendencje zmian użytkowania przestrzeni rolniczej obszarów karpackich. (Tendencies in the use of agricultural space in Carpathian areas). Studia i Raporty IUNG - PIB, Stan i kierunki zmian w produkcji rolniczej (wybrane zagadnienia). (State and directive of changes in agriculture production (selected issues). 17: 49-58.

26. TWARDY S., 1998. Pozatechniczne sposoby renowacji runi pastwisk górskich. (Non-technical methods of the restoration of mountain grassland sward). Łąkarstwo w Polsce, 1: 185-194.

27. Użytkowanie gruntów, powierzchnia zasiewów i pogłowie zwierząt gospodarskich w $2009 \mathrm{r}$. 2010 r. 2010, 2011. (Land use, crop areas and livestock in 2009-2011). Warszawa. GUS.

28. Wyniki produkcji roślinnej w 2009 r. 2010. (Results of plant production in 2009). Warszawa, GUS. 


\title{
STRESZCZENIE
}

\begin{abstract}
Aktualna rola użytków zielonych w rozwoju rolnictwa i obszarów wiejskich w Polsce - na przykladzie górskich województw małopolskiego i podkarpackiego
\end{abstract}

Słowa kluczowe: obsada zwierzat, rolnictwo, rejony górskie, trwate użytki zielone, rozwój obszarów wiejskich, wykorzystanie pasz

W niniejszej pracy przedstawiono obecną sytuację rolnictwa na terenach górskich w Polsce na przykładzie dwóch województw: małopolskiego i podkarpackiego. Podkreślono szczególna rolę, produkcyjną i ochronną jaką odgrywają trwałe użytki zielone w rozwoju obszarów wiejskich. Omówiono narzędzia wspierania i możliwości rozwoju rolnictwa w górskich obszarach wiejskich, takie jak płatności do obszarów ONW, płatności do chowu krów i owiec. Zaprezentowano również perspektywy rozwoju obszarów górskich, wśród których duże szanse upatruje się w systemie rolnictwa ekologicznego. 